\title{
The Price of Pay to Play in Securities Class Actions
}

\author{
Stephen J. Choi, Drew T. Johnson-Skinner, and A. C. Pritchard*
}

\begin{abstract}
We study the effect of campaign contributions to lead plaintiffs_- "pay to play"—on the level of attorney fees in securities class actions. We find that state pension funds generally pay lower attorney fees when they serve as lead plaintiffs in securities class actions than do individual investors serving in that capacity, and larger funds negotiate for lower fees. This differential disappears, however, when we control for campaign contributions made to officials with influence over state pension funds. This effect is most pronounced when we focus on state pension funds that receive the largest campaign contributions and that associate repeatedly as lead plaintiff with a single plaintiff's attorney firm. Thus, pay to play appears to increase agency costs borne by shareholders in securities class actions, undermining one of Congress's principal goals in adopting the Private Securities Litigation Reform Act.
\end{abstract}

\section{INTRODUCTION}

A principal goal of the Private Securities Litigation Reform Act (PSLRA) was to "empower investors so that they, not their lawyers, control securities litigation." ${ }^{\prime 1}$ Congress believed that individual investors who served as class representatives prior to the enactment of the PSLRA were largely figureheads dominated by class action lawyers. Because class action lawyers typically had a much greater interest in the class recovery than the named class representatives, plaintiffs may have lacked the incentive to monitor class counsel. To remedy that imbalance, the PSLRA created a presumption that courts should appoint as lead plaintiff the class member seeking appointment with the largest financial interest in the relief sought. ${ }^{2}$ Large shareholders, the theory went, would have more of an incentive to

\footnotetext{
*Address correspondence to A. C. Pritchard, University of Michigan Law School, 625 S. State St., Ann Arbor, MI 48109-1215; email: acplaw@umich.edu. Choi is Murray and Kathleen Bring Professor, New York University Law School; Johnson-Skinner is Associate, Lankler Siffert \& Wohl LLP; Pritchard is Frances and George Skestos Professor, University of Michigan Law School.

We thank two anonymous referees, Sanjai Bhagat, Un Kyung Park, Roberta Romano, David Webber, and participants at the American Law and Economics 2010 Annual Meeting, the NYU-Penn Finance Conference, the 14th Annual Law and Business Conference at Vanderbilt Law School, the 2010 Conference on Empirical Legal Studies, and the University of Toronto Law School Law and Economics Workshop for helpful comments on earlier versions of this article.
}

${ }^{1}$ S. Rep. No. 104-98 (1995). See also H.R. Conf. Rep. No. 104-369, at 32 (1995).

${ }^{2}$ Private Securities Litigation Reform Act of 1995, § 101(a), 15 U.S.C. § 77z-1(a) (3) (B) (2006). 
oversee lawyers who represent the class. Congress hoped that institutional shareholders serving as lead plaintiffs would negotiate with class counsel over attorney fees, ensuring that a larger share of the recovery would accrue to the class members.

In some ways, it appears that the PSLRA's lead plaintiff provision has succeeded. After a slow beginning, institutional investors have stepped forward to serve as lead plaintiffs in a substantial number of cases. The PSLRA has changed the game for class action lawyers, who must now compete for the favor of institutional investors in order to be selected as counsel. There is evidence that this competition has played an important role in reducing the percentage of the class recovery that goes to paying lawyers post-PSLRA.

There have been rumors, however, of another form of competition to garner the favor of institutional lead plaintiffs. Most of the institutional investors that have agreed to serve as lead plaintiffs in securities class actions have been government-sponsored pension funds. Many of these funds are managed directly by politicians, such as state comptrollers, who must campaign to retain their current positions, or may have designs on higher offices. Alternatively, these funds are managed by political appointees, who typically owe their position to the state's governor. The political influence over these funds raises the question of whether law firms are making campaign contributions to politicians to enhance their chances of being selected to represent the funds. The available anecdotal evidence raises suspicion that class action law firms are buying lead counsel status with campaign contributions, that is, lawyers are paying to play. But do campaign contributions affect the level of attorney fees paid in securities class actions? In other words, what is the price paid by class members if lawyers are paying to play?

This article presents the results of an empirical study shedding light on that question. Looking at securities class actions filed between 2002 and mid-2007, we find that the presence of a state pension fund as lead plaintiff correlates with significantly lower attorney fees. We also find that larger funds, of all types, tend to negotiate lower attorney fees. State pension funds whose managers have received campaign contributions, however, appear to be less vigorous in negotiating attorney fees. The state pension funds whose officials received the largest contributions from the lead attorney firms negotiate for attorney fees that are statistically indistinguishable from the fees in cases with individual investors serving as lead plaintiffs. Thus, political contributions to lead plaintiffs appear to undermine at least one of Congress's objectives in enacting the PSLRA's lead plaintiff provision.

We proceed as follows. Section II provides background on the lead plaintiff provision and develops hypotheses relating to political influence on lead plaintiff pension funds. Section III describes our sample and sources of data. Section IV presents the results of the empirical tests of our hypotheses. Section V concludes with a discussion of the legal and policy implications of our findings.

\section{BACKGROUND AND Hypotheses}

\section{A. Prior Literature}

One of the abuses of securities class actions that Congress attempted to address in enacting the PSLRA was "the manipulation by class action lawyers of the clients whom they 


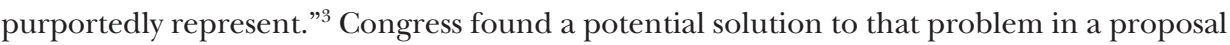
by Weiss and Beckerman (1995). Weiss and Beckerman argued that institutional investors, if placed in the lead plaintiff role, would act as effective monitors of plaintiffs' attorneys' actions in securities class action litigation. Congress acted on Weiss and Beckerman's proposal in adopting the PSLRA's lead plaintiff provision. That provision established a "rebuttable presumption ... that the most adequate plaintiff . . . is the person or group of persons that... has the largest financial interest in the relief sought by the class." ${ }^{4}$ The PSLRA also stated that the most adequate plaintiff will "select and retain counsel to represent the class." ${ }^{\text {Th }}$ The premise of the PSLRA's lead plaintiff provision is that larger investors, with larger stakes in the class recovery, would serve as more effective monitors of class counsel. By providing effective monitoring, the lead plaintiff would protect the interests of the absent class members.

Congress worried, however, about the potential for lead plaintiff monitoring to be undermined by side payments, leading Congress to include a provision in the PSLRA prohibiting non-pro-rata payments to the lead plaintiff. ${ }^{6}$ Such payments were rumored to have been an issue in securities class actions prior to the adoption of the PSLRA. (Those rumors appear to have been well founded; several former partners of the Milberg Weiss law firm, now "Milberg," have gone to prison for hiding such payments from courts overseeing securities class actions (Selvin 2008).) Those payments raised concerns that class representatives would not have an incentive to protect the interests of absent class members. One measure of lead plaintiff monitoring is attorney fees; vigilant monitors presumably would negotiate lower fees, which would mean a greater net recovery for class members. Consistent with this theory, Perino (2008) finds that Milberg Weiss's attorney fees were significantly higher for cases in which side payments were made to lead plaintiffs (as identified in the indictment against the firm) than in those cases in which payments were not made.

There is considerable evidence that the PSLRA's lead plaintiff provision has led to improved monitoring of class counsel. Choi et al. (2005) report that public pension funds' participation as lead plaintiff increased significantly after the PSLRA's enactment. They also report that the presence of public pension funds correlates with high-value settlements. Simmons and Ryan (2005) and Cox and Thomas (2006) also report that institutional lead plaintiffs correlate with increased settlement amounts. Cox et al. (2008) similarly report that institutional investor lead plaintiffs, in particular public pension funds and labor unions, are positively related to larger settlement amounts. These studies suggest

\footnotetext{
${ }^{3}$ See H.R. Rep. No. 369, at 31 (1995), reprinted in 1996 U.S.C.C.A.N. 730, 1103.

${ }^{4} 15$ U.S.C. $\$ 78 \mathrm{u}-4$ (a) (3) (B) (iii) (I).

${ }^{5} 15$ U.S.C. $\$ 78 \mathrm{u}-4(\mathrm{a})(3)(\mathrm{B})(\mathrm{v})$.

${ }^{6} 15$ U.S.C. $\$ 78 \mathrm{u}-4(\mathrm{a})(4)$.
} 
that institutional investors who serve as lead plaintiffs may be promoting larger recoveries for shareholder class members. ${ }^{7}$

Choi et al. (2005) also examine the relationship of lead plaintiffs and attorney fees. They report that attorney fees, measured as a percentage of recovery, if anything, are higher with private institutional lead plaintiffs after the enactment of the PSLRA compared with the pre-PSLRA period; they also report no significant correlation exists between fees and public pension funds postenactment once they control for the size of the case. Their study looked only at cases filed from 1991 to 2000 , so it antedates the time that institutional investors stepped forward in large numbers to serve as lead plaintiff. Perino (2006), looking at a larger sample of cases from 1995 to 2004, reports that attorney fees granted by a court are lower with public pension fund lead plaintiffs, even after controlling for the presence of accounting restatements and SEC investigations, which are indicators of potentially high-value cases.

There have been media reports of political contributions to the lead plaintiff being linked to the plaintiff's lead counsel selection for some time, but little systematic analysis. For example, Fortune magazine ran a story detailing political contributions received by former New York State Comptroller Carl McCall from the partners at Bernstein, Litowitz, Berger \& Grossman (BLBG) (Weinberg \& Fisher 2004). McCall received these contributions shortly before McCall chose BLBG to serve as the New York public pension fund's counsel in the WorldCom securities class action.

McCall was also involved in perhaps the most frequently cited example of pay to play in securities cases, In re Cendant Corp. Litigation. The district court in Cendant discovered that two law firms selected as lead counsel contributed nearly $\$ 200,000$ to McCall, who was the sole director of the New York public pension fund that was a lead plaintiff in the case (Dewan 2002). The district court in Cendant, however, declined to find that pay to play took place, and this finding was affirmed by the Court of Appeals for the Third Circuit. ${ }^{8}$ The Cendant court's skepticism that pay to play had an important influence on counsel selection is typical; a district court in California recently rebuffed as "speculative" arguments that political contributions created a conflict between the attorney and the class. ${ }^{9}$ The court noted that " $[\mathrm{c}]$ ourts have long been less enamored of securities litigation pay-to-play arguments than litigants and the press."

Johnson-Skinner (2009) provides the first systematic effort to document pay to play. He presents summary statistics of law firm political contributions side by side with pension funds' selection of law firms as counsel in securities class actions from 2002 to 2006. He finds that law firms do contribute to the officials of funds that select them as class counsel in a substantial number of cases. By contrast, Webber (2010) rejects arguments that pay to play has a substantial influence on counsel selection based on his finding that the number of

\footnotetext{
${ }^{7}$ There may be a selection effect at work. If public pension funds choose only to participate as lead plaintiff when the litigation involves large potential damage amounts and a higher probability of recovery, there may be a correlation between public pension funds' participation and larger settlement amounts, but not a direct causal relationship. Because of the uncertain causality, we do not directly examine the link between pay to play and settlement amounts.
}

${ }^{8}$ In re Cendant Corp. Litig., 264 F.3d 201, 269 (3d Cir. 2002).

${ }^{9}$ In re Countrywide Fin. Corp. Sec. Litig., 273 F.R.D. 586, 604 (C.D. Cal. 2009). 
politicians on pension fund boards correlates negatively with selection as lead counsel. Unlike Johnson-Skinner, however, Webber does not examine the influence of campaign contributions, which would seem to be a more direct measure of the incidence of pay to play.

Untangling the causal relation between the campaign contributions and the selection of lead counsel is difficult. On the one hand, campaign contributions may lead to a higher likelihood that a public pension fund lead plaintiff will select the contributing law firm as lead counsel. On the other hand, a law firm may simply provide superior legal services, leading both to greater law firm profits (and thus more campaign contributions) as well as a higher likelihood that the law firm will be selected as lead counsel. Neither JohnsonSkinner nor Webber addresses this causality issue. We focus in this study more directly on the conflict between the lead counsel and the class in our examination of attorney fees, which are assessed against the class recovery. We study the effect of campaign contributions on attorney fees.

\section{B. Hypotheses}

As discussed above, Congress believed that individual investors serving as lead plaintiffs were ineffective monitors; plaintiffs with larger stakes in the class recovery were more likely to negotiate lower attorney fees with class counsel. The PSLRA's lead plaintiff provision encourages institutional investors to step forward as plaintiffs, but these investors vary in their size and sophistication. State-level public pension funds are typically the largest and most sophisticated. Smaller institutions, however, such as local government and labor union pension funds, have also volunteered to serve as lead plaintiffs. Finally, individuals continue to serve as lead plaintiffs in a substantial percentage of cases.

With their large, diverse portfolios, state pension funds have the greatest leverage because they can offer lawyers additional opportunities to serve as lead counsel in subsequent cases. The PSLRA limits the number of times any one entity or individual may serve as lead plaintiff to no more than five times in any three-year period, ${ }^{10}$ but this restriction is subject to rebuttal. Moreover, individual state pension fund officials may control a number of different pension funds, enabling them to skirt the PSLRA's limit. For example, in Louisiana, the Chairman of the Louisiana Senate Retirement Committee sits on the board of trustees for the Louisiana Municipal Police Employees' Retirement System, the Teachers' Retirement System of Louisiana, and the Louisiana Sheriffs' Pension and Relief Fund, among others.

We postulate a continuum of investor types when it comes to negotiating over attorney fees, with larger institutions, such as state pension funds, being the most effective in negotiating lower fees. ${ }^{11}$ Other institutions, such as local government pension

\footnotetext{
${ }^{10}$ See Private Securities Litigation Reform Act of 1995, 15 U.S.C. $§ 77 z-1$ (a) (3) (B) (vi) (2006).

${ }^{11}$ Larger funds and state pension funds may negotiate lower fees either because they are better at bargaining with the plaintiffs' attorneys or because they are better monitors of attorney effort and therefore can stimulate increased attorney effort without promising the attorneys an increased share of a potential settlement. In either case, we predict that larger funds and state pension funds will generally correlate with lower attorney fees unless, as our article examines, the fund officials receive large campaign contributions from the law firm representing the class.
} 
funds and labor unions, may have a greater stake than individual investors, but they may lack the legal sophistication and bargaining power of the large state pension funds. We postulate that individual investors will exercise the least influence in negotiating over attorney fees.

Hypothesis 1: State public pension funds will negotiate the lowest attorney fees, local government pension funds and labor unions will negotiate intermediate fees, and individual lead plaintiffs will negotiate the highest.

Hypothesis 1 follows the governing premise of the PSLRA's lead plaintiff provision in positing that investors with a larger stake in the class recovery will serve as better monitors of the class's interests. This incentive for better monitoring, however, may be undermined if the decisionmakers for the institutional lead plaintiffs receive a selective benefit-for example, campaign contributions-not shared by other class members. Congress worried about the effect of selective benefits when it adopted the prohibition against non-pro-rata payments to class members discussed above.

We use attorney fees as our measure of lead plaintiff monitoring. We hypothesize that political contributions to state pension funds acting as the lead plaintiff-we call plaintiffs that have received contributions "conflicted"-may reduce the incentive of the lead plaintiffs to negotiate vigorously with the lead counsel and may lead to correspondingly higher attorney fees. Moreover, we postulate that attorney fees are likely to correlate with the size of the contributions to the state pension funds-the greater the contribution, the greater the fee.

Hypothesis 2: Attorney fees negotiated by conflicted state pension fund lead plaintiffs will be no different than attorney fees negotiated by individual plaintiffs.

Hypothesis 3: Attorney fees will correlate with the size of the political contributions made to the state pension fund lead plaintiffs.

Hypothesis 3 postulates that larger political contributions create more conflict with the interests of class members. We also posit that larger political contributions will also diminish the incentives of state pensions with greater assets under management and/or higher losses in a particular case to negotiate for lower attorney fees. These state pensions would normally have a greater ability and incentive to monitor plaintiffs' attorneys. To the extent political contributions affect the incentives of such pension funds, the impact on attorney fees will be correspondingly larger as a result.

Another measure of that conflict is the pervasiveness of those contributions and the strength of the connection between state pensions and particular law firms. Do state pensions select different law firms as lead counsel for different cases, or do they frequently select the same law firm? Are they more likely to select the same firm if the firm made campaign contributions to fund officials? If a fund is consistently represented by the same law firm, and that firm has made campaign contributions to fund officials, the fund may scrutinize fees less carefully. Accordingly, we postulate that state pension fund lead plaintiffs who are frequently represented by the same class counsel who made campaign contributions are likely to agree to pay higher fees relative to other state pension funds. 
Hypothesis 4: Attorney fees will be higher in cases in which the state pension fund lead plaintiffs are frequently represented by the same securities class actions attorneys who have made campaign contributions.

\section{SAmple and Descriptive Statistics}

\section{A. Sample}

To test our hypotheses, we use the securities class actions filed from 2002 to mid-2007. ${ }^{12}$ We obtain the suits from the Stanford Securities Clearinghouse. We exclude cases in which financial firms (SIC 6000 to 6999) are the primary defendant because of the different regulatory regime that applies to them; with this exception, we analyze the population of suits filed during this period.

Our key dependent variable is the requested attorney fee award negotiated between the lead plaintiff and the lead counsel measured as a percentage of the settlement amount (Atty_Fee). We obtain the requested fee from fee motions filed in connection with settlements, which must be approved by the court. We accordingly have attorney fee information only for settled cases.

Table 1 shows that slightly more than half the cases filed during our sample period have been settled, giving us 408 settled class actions. The filing years for our settled cases are

Table 1: Sample Description

\begin{tabular}{|c|c|c|c|}
\hline \multicolumn{4}{|c|}{ Panel A: Full Sample } \\
\hline \multicolumn{2}{|l|}{ Outcome } & Freq. & Percent \\
\hline \multicolumn{2}{|l|}{ Settlement } & 408 & 54.11 \\
\hline \multicolumn{2}{|c|}{ Settlement $\leq \$ 3 \mathrm{M}$} & 102 & 13.53 \\
\hline \multicolumn{2}{|c|}{ Settlement >\$3 M. } & 306 & 40.58 \\
\hline \multicolumn{2}{|c|}{ Trial verdict or judgment on pleadings for plaintiff } & 2 & 0.27 \\
\hline \multicolumn{2}{|l|}{ Dismissal } & 327 & 43.37 \\
\hline \multicolumn{2}{|c|}{ Class certification denied } & 2 & 0.27 \\
\hline \multicolumn{2}{|c|}{ Summary judgment or trial verdict for defendant } & 15 & 1.99 \\
\hline \multicolumn{2}{|l|}{ Total } & 754 & 100.00 \\
\hline \multicolumn{4}{|c|}{ Panel B: Settlement Sample } \\
\hline Year of Filing & Freq. & & Percent \\
\hline 2002 & 113 & & 27.70 \\
\hline 2003 & 79 & & 19.36 \\
\hline 2004 & 90 & & 22.06 \\
\hline 2005 & 69 & & 16.91 \\
\hline 2006 & 50 & & 12.25 \\
\hline 2007 & 7 & & 1.72 \\
\hline Total & 408 & & 100 \\
\hline
\end{tabular}

\footnotetext{
${ }^{12}$ The sample is based on the data set in Choi (2011).
} 
Table 2: Summary Statistics for Settled Class Actions

\begin{tabular}{lcccc}
\hline & $\mathrm{N}$ & Mean & Median & SD \\
\hline Rule 10b-5 & 398 & 0.965 & 1.000 & 0.184 \\
Section 11 & 398 & 0.214 & 0.000 & 0.410 \\
Section 14 & 398 & 0.038 & 0.000 & 0.191 \\
Restatement & 395 & 0.468 & 0.000 & 0.500 \\
Gov't investigation & 395 & 0.527 & 1.000 & 0.500 \\
Officer termination & 395 & 0.392 & 0.000 & 0.489 \\
Auditor termination & 395 & 0.078 & 0.000 & 0.269 \\
Insider trading & 394 & 0.523 & 1.000 & 0.500 \\
Settlement amount & 400 & 58.9 & 7.4 & 374.3 \\
Market capitalization & 391 & 4335.7 & 497.6 & 15730.0 \\
Turnover & 385 & 0.876 & 0.976 & 0.206 \\
Minimum return & 386 & -0.286 & -0.269 & 0.147 \\
High tech & 397 & 0.161 & 0.000 & 0.368 \\
FDA & 395 & 0.041 & 0.000 & 0.197 \\
Resolution time & 392 & 1143.7 & 1039.5 & 477.9 \\
Top attorney firm & 344 & 0.552 & 1.000 & 0.498 \\
\hline
\end{tabular}

Note: Variable definitions are in the Appendix.

somewhat skewed toward the beginning of the sample period, as many of the suits filed in the later years remain unresolved.

\section{B. Control Variables}

Descriptive statistics regarding the cases are presented in Table 2. We use the following set of variables in each of our multivariate models as controls (collectively referred as "Case Controls"). The controls are relevant to the strength of the case, which is likely to determine the difficulty of extracting a settlement. More difficult cases may generate higher attorney fees. We collect information on key aspects of the litigation from the last amended complaint available for each class action. ${ }^{13}$

From the complaints, we collect information about the causes of action alleged to create indicator variables for those causes. Over 95 percent of the cases alleged a Rule 10b-5 claim under the Securities Exchange Act of 1934; 21.4 percent of the cases alleged a Section 11 claim under the Securities Act of 1933 (SEction 11); 3.8 percent of the cases alleged a Section 14(a) claim under the Securities Exchange Act of 1934 (SEction 14). Section 11 is available only for material misstatements and certain omissions in the registration statement used in a public offering, but it allows for a substantially greater chance of surviving a motion to dismiss because Section 11 does not require plaintiffs to plead fraudulent intent, and loss causation and due diligence are affirmative defenses, rather than elements of the claim. Claims under Section 14 of the Exchange Act relating to misstatements in a proxy statement have a lower standard for state of mind and loss causation than Rule 10b-5.

\footnotetext{
${ }^{13}$ As described in Choi (2011), the complaints and other securities-docket-related documents were collected from the PACER website.
} 
We also include as controls certain indicator variables based on the allegations in the complaint. These allegations are intended to satisfy the pleading standards, which are the principal barriers to recovery in securities class actions (Johnson et al. 2007). We include in our Case Controls variables for SEC and other government investigations (GOV't INVESTIGATION) and accounting restatements (RESTATEMENT), each a high-profile adverse event and the most common events triggering these suits. The presence of a government investigation or a restatement indicates a higher likelihood of wrongdoing and thus a stronger case for the plaintiffs. The overall strength of the case will also be bolstered if the firm has terminated a top officer, including the chief executive officer, chief operating officer, and chief financial officer (OFFICER TERM.) or its auditor (AUDITOR TERM.), due to events relating to the fraud. We also include whether the complaint alleges insider trading (INSIDER TRADING), which suggests fraudulent intent.

We also include variables in our Case Controls relating to the firm-specific characteristics of the defendant issuer, which correlate with the damages measure and the defendant's ability to pay a settlement. We include a measure of firm size, measured as market value of equity measured at the end of the fiscal year preceding the beginning of the class period (MARKET CAPITALIZATION). Larger firms may have greater resources to defend against a class action. On the other hand, larger firms may also be better able to pay a settlement, leading to more vigorous prosecution of the case by plaintiffs' attorneys. We include the settlement amount (SETTLEMENT AMOUNT) because prior studies report a close relationship between settlement amount and the attorney fee award (e.g., Eisenberg \& Miller 2004). To control for possible nonlinearities in the relationship between attorney fees and the settlement amount, we include the settlement amount squared (SETTLEMENT AMOUNT $^{2}$ ). We also include the share turnover during the class period (TURNOVER) and the minimum one-day return during the class period plus the day after the end of the class period (MINIMUM RETURN) for the company at issue in the complaint. These variables are correlated with the amount of potential damages investors may obtain in a securities class action (e.g., Jones \& Weingram 1996; Francis et al. 1994). The greater the turnover (which increases cumulatively with class period length) and minimum return, the greater the computed damage measure under Rule 10b-5.

We also include two industry controls that may relate to case strength and loss causation. Firms in the high-technology sector (HIGH TECH $)^{14}$ may have stock prices that are particularly vulnerable to declines in sales or earnings. Additionally, firms involved in the pharmaceutical and medical devices industries may experience steep stock price declines if the U.S. Food and Drug Administration denies approval of their new products. To capture this effect, we include an indicator variable (FDA) equal to 1 if the last amended complaint for the class action contains allegations based on Food and Drug Administration related disclosures; 0 otherwise.

The attorney fees may depend on time needed to resolve the litigation. If a case settles soon after the initial filing, the plaintiffs' attorneys may face reduced risk and have expended little effort-resulting in a lower attorney fee as a percentage of the settlement

\footnotetext{
${ }^{14}$ We define High тесн as equal to 1 if the firm is in SIC codes $3570-3577$ or $7370-7379$; 0 otherwise.
} 
amount. In contrast, if a case settles only after lengthy discovery and settlement negotiations, the attorneys face greater risk and will have expended more effort-resulting in a higher attorney fee as a percentage of the settlement amount. Accordingly, we include the number of days from the initial filing of suit to the settlement date as a control (RESOLUTION TIME).

Finally, the attorney fees may also turn on the identity of the plaintiffs' law firm. Larger law firms may have economies of scale that allow them to charge a lower fee, all else equal, for the same amount of work and results in a securities class action. We define a variable, TOP ATTORNEY FIRM, as equal to 1 if any of the lead counsel in the specific class action participated 50 or more times as a lead counsel in a class action in the data set; 0 otherwise. The top attorney firms include Milberg Weiss Bershad Hynes \& Lerach LLP, Milberg Weiss Bershad \& Schulman LLP, Lerach Coughlin Stoia Geller Rudman \& Robbins LLP, and Schiffrin \& Barroway LLP.

\section{Plaintiff Type}

For each class action, we collect data from PACER, Westlaw, and the Securities Class Action Clearinghouse on the federal district court docket and the motions for lead plaintiff. Lead plaintiffs usually are combined in a lead plaintiff group of several investors. These groups typically are created to resolve disputes among plaintiffs' attorney firms competing to be named as counsel to the class (Choi 2011). Individuals are the type of plaintiff that Congress found wanting when it enacted the PSLRA.

Table 3, Panel A provides descriptive statistics regarding the type of investors selected as lead plaintiffs. Institutional investors appear as part of the lead plaintiff group in over half (58.9 percent) of the cases in our sample, confirming earlier work showing that institutional investors are important players in securities class actions. Public pension funds appear in 18.7 percent of the cases in our sample; with slightly more state (9.7 percent) than local (9.0 percent) funds. Labor unions (21.7 percent) and other institutions (26.7 percent) are also well represented. Individuals, however, continue to predominate as class representatives; they are the only members of the lead plaintiff group in 41.2 percent of the cases. State pension funds are the primary focus of our analysis; individual lead plaintiffs provide the baseline for comparison.

Table 3, Panel B provides descriptive statistics comparing the assets under management and losses related to the class actions for the different types of institutions acting as lead plaintiff. ${ }^{15}$ As expected, the state pension funds are larger than their local counterparts and labor union funds. The average (median) state pension fund in our sample has nearly $\$ 20.4$ billion ( $\$ 11.2$ billion) under management, while the local funds manage an average of $\$ 7.0$ billion ( $\$ 0.4$ billion). The difference between the two means is significant at the 1 percent level. State pension funds also had larger securities losses related to the class action. The average (median) state pension fund in our sample had $\$ 10.4$ million ( $\$ 1.9$ million) losses in cases for which it acted as lead plaintiff while the local funds averaged losses of $\$ 1.3$

\footnotetext{
${ }^{15}$ Data on assets were collected from FreeERISA.com or from the pension fund's annual report. The assets measurement is for 2005. Data are not available on the assets of other institutions or individuals.
} 
Table 3: Lead Plaintiffs for Settled Class Actions

Panel A: Lead Plaintiff Types

\begin{tabular}{lccc}
\hline Lead Plaintiff & $\begin{array}{c}\text { Cases with at Least One } \\
\text { Lead Plaintiff of the Type }\end{array}$ & $\begin{array}{c}\text { Mean Fraction of } \\
\text { Pead Plaintiffs per Case }\end{array}$ \\
\hline Institution & 165 & $58.9 \%$ & 0.149 \\
Public Pension & 75 & $18.7 \%$ & 0.071 \\
$\quad$ State & 39 & $9.7 \%$ & 0.078 \\
$\quad$ Local & 36 & $9.0 \%$ & 0.156 \\
Labor union & 87 & $21.7 \%$ & 0.171 \\
Other institution & 107 & $26.7 \%$ & \\
\hline Lead Plaintiff & Cases & Percentage of Cases & \\
\hline Individual only & 165 & $41.2 \%$ & \\
Total cases with lead & 401 & $100.0 \%$ & \\
$\quad$ plaintiff information & & & \\
\hline
\end{tabular}

Panel B: Pension Fund Assets and Losses

\begin{tabular}{|c|c|c|c|c|c|c|c|}
\hline Lead Plaintiff & & $\mathrm{N}$ & Mean & p 25 & Median & p 75 & SD \\
\hline \multirow[t]{2}{*}{ Public pension } & Assets & 72 & 14280.3 & 579.2 & 5109.7 & 16864.8 & 20893.7 \\
\hline & Losses & 49 & 4.8 & 0.2 & 0.9 & 2.9 & 12.1 \\
\hline \multirow[t]{2}{*}{ State } & Assets & 39 & 20402.0 & 5584.2 & 11225.9 & 36422.3 & 22877.9 \\
\hline & Losses & 19 & 10.4 & 0.7 & 1.9 & 14.4 & 18.1 \\
\hline \multirow[t]{2}{*}{ Local } & Assets & 33 & 7045.5 & 112.1 & 447.6 & 3666.4 & 15729.0 \\
\hline & Losses & 30 & 1.3 & 0.1 & 0.5 & 1.4 & 2.5 \\
\hline \multirow[t]{2}{*}{ Labor union } & Assets & 85 & 1160.1 & 222.7 & 507.3 & 919.4 & 2881.7 \\
\hline & Losses & 61 & 1.0 & 0.1 & 0.3 & 0.6 & 2.4 \\
\hline
\end{tabular}

Panel C: Requested Attorney Fees

\begin{tabular}{lcccccc}
\hline Lead Plaintiff & $\begin{array}{c}\text { Cases with at Least One } \\
\text { Lead Plaintiff of the Type }\end{array}$ & Mean & p 25 & Median & p 75 & SD \\
\hline Public pension & 61 & 0.215 & 0.180 & 0.225 & 0.250 & 0.057 \\
State & 36 & 0.196 & 0.168 & 0.195 & 0.246 & 0.052 \\
Local & 25 & 0.242 & 0.225 & 0.250 & 0.250 & 0.053 \\
Labor union & 76 & 0.253 & 0.243 & 0.250 & 0.300 & 0.058 \\
Other institution & 99 & 0.265 & 0.250 & 0.250 & 0.300 & 0.054 \\
Individual only & 138 & 0.280 & 0.250 & 0.300 & 0.300 & 0.051 \\
Total & 353 & 0.262 & 0.250 & 0.250 & 0.300 & 0.058 \\
\hline
\end{tabular}

Note: In Panel A, mean fraction of lead plaintiffs per case is computed based on the mean across all cases with a settlement where we had lead plaintiff information. Attorney fee requests are a percentage of the settlement amount. In Panel B, assets are in millions of dollars, measured as of 2005. Losses are in millions of dollars.

million ( $\$ 0.5$ million). The difference between the two means is significant at the 5 percent level. Labor unions manage the least in assets, with an average of $\$ 1.2$ billion ( $\$ 0.5$ billion), with correspondingly lower losses, an average of $\$ 1.0$ million (\$0.3 million).

Panel C of Table 3 reports the mean requested attorney fees for the settlements in our sample broken down by plaintiff type. Overall, the mean fee request is 26.2 percent of 
the settlement amount. The smallest requested fee in our sample was 7 percent and the largest was 35 percent. The mean requested fee for cases involving at least one state pension lead plaintiff is 19.6 percent of the settlement amount. In comparison, the mean requested fee for cases in which the lead plaintiffs are individuals is 28.0 percent of the settlement amount.

\section{Political Contributions}

Having identified the lead plaintiffs in our sample, we collected data on contributions to politicians connected to state pension funds. We first identified the membership of the controlling boards of the plaintiff institutions at the time the case was filed. For board positions that were ex officio, we determined who held the relevant office at the time of filing the complaint. For positions that were appointed by an elected official, we also determined who held that elected office at the time of filing.

Next, we identified the plaintiff law firms that were selected as counsel by the funds in each case. If there was more than one plaintiff law firm for a given case, which was typically the case when there was more than one lead plaintiff in the case, all the lead plaintiffs and all the law firms were grouped together. For purposes of determining the total level of campaign contributions, we treated a contribution by any law firm to any public pension lead plaintiff as a contribution.

We then used state-level campaign finance filings to find instances of political contributions from the identified law firms to any of the elected officials associated with the pension funds that actually selected the firms. ${ }^{16}$ We searched for contributions from 1998 through 2008. The search allowed us to look for both contributions by the firm and by individuals who list the firm as their employer. Note that this method is underinclusive as it typically does not discover any donors who did not indicate their employer. We also searched for contributions to the relevant elected officials' state political party committees (e.g., the state Democratic Party for a Democrat) in an attempt to find indirect contributions. ${ }^{17}$

We use these contribution data to construct two variables. The first, CONTRIBUTIONFUND OFFICIALS, includes contributions made to officials who serve on the governing body of the state pension fund, or who appoint members of the governing body of the fund. We include contributions from a four-year window, beginning two calendar years prior to the suit filing and ending one calendar year after. This four-year window allows us to limit the contributions to those most directly related to the suit filing, while still ensuring that one election cycle would be included. ${ }^{18}$ The second, Contribution-All STATE OfFicials,

\footnotetext{
${ }^{16}$ The source of these data is followthemoney.org.

${ }^{17}$ Our data are underinclusive in another way because we were unable to locate systematic data for contributions to local politicians affiliated with the local pension funds in our sample. We found press reports of such contributions in isolated cases, and a handful of large municipalities have websites showing such contributions to funds in our sample. We could not collect these data for the majority the local government pension funds in our sample, however, so we have not relied on any contributions to local politicians in our analysis. Thus, our findings are likely to understate the influence of pay to play, which appears to also affect local pension funds.
}

${ }^{18}$ Use of this window required the exclusion of one observation that had two elections during the four-year window. 
Table 4: Campaign Contributions

Panel A: Attorneys' Contributions to State Pension Fund Lead Plaintiffs

\begin{tabular}{lccrrr}
\hline & \multicolumn{4}{c}{ Cases $\geq$ One State } \\
& Cases & Pension Lead Plaintiff & Mean & Median & SD \\
\hline Contribution-fund official & 19 & $48.7 \%$ & 9838 & 10000 & 6173 \\
Contribution-any state official & 24 & $61.5 \%$ & 60975 & 25950 & 113727
\end{tabular}

Panel B: Number of Unique State Lead Plaintiffs

\begin{tabular}{lcc}
\hline & Cases & Unique States \\
\hline State pension-contribution & 19 & 8 \\
State pension-no contribution & 20 & 9 \\
\hline
\end{tabular}

Panel C: Requested Attorney Fees by Contribution

\begin{tabular}{lcccccr}
\hline & Cases & Mean & p 25 & Median & p 75 & SD \\
\hline State pension-contribution & 16 & 0.202 & 0.182 & 0.210 & 0.250 & 0.059 \\
State pension-no contribution & 20 & 0.191 & 0.152 & 0.183 & 0.236 & 0.046
\end{tabular}

$p$ value $=0.532$ from a difference in means between state pension-contribution and state pension-no contribution .

NotE: Source for contributions is followthemoney.org. Fund official is for contributions made to officials who serve on the governing body of the state pension fund, or who appoint members of the governing body of the fund. All state officials includes all elected officials and political committees in the state.

is a broader measure of a law firm's political activity in the state that includes contributions not only to fund officials, but also to all elected officials and political committees in the state. This measure is more inclusive, but also potentially noisier, as it may capture contributions unrelated to securities class action representation. This variable also uses the four-year window described above.

Table 4 presents descriptive statistics showing the results of this research into political contributions. Panel A of Table 4 indicates that a little under half ( 48.7 percent) of the state pension fund lead plaintiffs in our sample received campaign contributions from the lead attorneys associated with the case in which the fund was serving as lead plaintiff. For these pension funds, the mean contribution received by all of its officials was relatively small at $\$ 9,838$ and the median contribution was $\$ 10,000$. Using our broader measure of contributions to any state official, we find a mean of $\$ 60,975$ and a median of $\$ 25,950$.

Panel B of Table 5 details the number of unique states from which come the state pension funds acting as lead plaintiffs. We divide state pension funds into two categories: STATE PENSION-CONTRIBUtion and STATE PENSION-NO CONTRIBUtion. The former is the fraction of lead plaintiffs in the case that consists of state pension funds with officials who received political contributions from the lead attorneys, and the latter reflects state pension funds with officials who did not receive such political contributions. States typically will act as lead plaintiffs in multiple class actions (and as a result the number of unique states acting as lead plaintiffs is less than the number of cases). Nonetheless, as reported in Panel B, our sample of 19 cases with a state pension fund lead plaintiff that received a political contribution from the lead attorneys involves eight unique states. Our sample of 20 cases with a 
state pension fund lead plaintiff that did not receive political contributions from the lead attorneys involves nine unique states. The ratio of cases to unique states is similar for both categories of state pension funds. This suggests that the pay for play phenomenon that we test is not limited to a single outlier state.

Panel $\mathrm{C}$ of Table 5 details the breakdown of requested attorney fees by STATE PENSION-CONTRIBUtion and STATE PENSION-NO CONTRIBUtion. At the 25th percentile, median, 75th percentile, and mean, the requested attorney fees are higher for state funds that received a political contribution compared with state funds that did not receive a political contribution. The difference in means, however, is not significant. We use multivariate regressions below in our empirical tests to explore further the relationship between attorney fees and contributions.

\section{EMPIRICAL Tests}

\section{A. Pension Fund Type, Assets, and Attorney Fees}

We postulate in Hypothesis 1 that the type of lead plaintiff will correlate with the size of attorney fees. To test this hypothesis, we estimate an ordinary least squares model with the log odds of the requested attorney fee percentage of the settlement as the dependent variable (using case-level data and robust standard errors). Our main independent variable of interest is the fraction of the lead plaintiffs in a case that consist of a state pension fund (state PENSiON). We also include the fraction of the lead plaintiffs that consist of a local pension fund (LOCAL PENSION), or a labor union (LABOR UNION), and the fraction of lead plaintiffs that are institutions but not government pension funds or labor unions (OTHER INSTITUTION). The regression assesses the effect of these variables relative to our baseline category of individual-only lead plaintiffs. We also include the Case Controls described above.

$$
\begin{gathered}
\ln \left(\text { Atty_Fee }_{\mathrm{i}} / 1-\text { Atty_Fee }_{\mathrm{i}}\right)=\alpha+\beta_{1 \mathrm{i}} \text { State }_{\text {Pension }}+\beta_{2 \mathrm{i}} \text { Local Pension }_{\mathrm{i}}+ \\
\beta_{3 \mathrm{i}} \text { Labor Union }_{\mathrm{i}}+\beta_{4 \mathrm{i}} \text { Other Institution }_{\mathrm{i}}+\text { Case Controls }+\varepsilon_{\mathrm{i}}
\end{gathered}
$$

The results are presented in Table 5, Model 1. Negative coefficients for the independent variables correlate with lower attorney fees, suggesting more vigorous negotiating by the lead plaintiff. Consistent with Hypothesis 1, we find that state pension fund lead plaintiffs correlate with significantly lower attorney fees, as do local pension funds. Both coefficients are significant at the 1 percent level. Assessed at the mean of all independent variables, a 50 percentage point increase in the fraction of lead plaintiffs that consists of state pension funds correlates with a 4.2 percentage point decrease in the attorney fee request (or 16.0 percent of the mean requested attorney fees). Similarly, a 50 percentage point increase in the fraction of lead plaintiffs that consists of local pension funds correlates with a 2.6 percentage point decrease in the attorney fee request (or 10.0 percent of the mean requested attorney fees). The coefficient for LABOR UNION is negative, but considerably smaller in magnitude and not significantly different from zero. Thus, labor unions are 
Table 5: Assets and Attorney Fees

\begin{tabular}{|c|c|c|}
\hline & Model 1 & Model 2 \\
\hline State pension & $\begin{array}{l}-0.466 * * \\
(-5.36)\end{array}$ & \\
\hline State pension-above median assets & & $\begin{array}{l}-0.582 * * \\
(-5.59)\end{array}$ \\
\hline State pension-below median assets & & $\begin{array}{l}-0.262 * \\
(-2.10)\end{array}$ \\
\hline Local pension & $\begin{array}{l}-0.283^{* *} \\
(-3.13)\end{array}$ & \\
\hline Local pension-above median assets & & $\begin{array}{l}-0.561 * * \\
(-3.69)\end{array}$ \\
\hline Local pension-below median assets & & $\begin{array}{l}-0.077 \\
(-1.07)\end{array}$ \\
\hline Labor union & $\begin{array}{l}-0.024 \\
(-0.48)\end{array}$ & \\
\hline Labor union-above median assets & & $\begin{array}{l}-0.042 \\
(-0.68)\end{array}$ \\
\hline Labor union-below median assets & & $\begin{array}{l}-0.005 \\
(-0.08)\end{array}$ \\
\hline Other institution & $\begin{array}{l}-0.103^{+} \\
(-1.80)\end{array}$ & $\begin{array}{l}-0.107^{+} \\
(-1.86)\end{array}$ \\
\hline Section 11 & $\begin{array}{l}-0.023 \\
(-0.57)\end{array}$ & $\begin{array}{l}-0.024 \\
(-0.58)\end{array}$ \\
\hline Section 14 & $\begin{array}{l}-0.277 * \\
(-2.18)\end{array}$ & $\begin{array}{l}-0.243^{+} \\
(-1.88)\end{array}$ \\
\hline Restatement & $\begin{array}{c}0.022 \\
(0.57)\end{array}$ & $\begin{array}{c}0.012 \\
(0.30)\end{array}$ \\
\hline Gov't investigation & $\begin{array}{l}-0.060 \\
(-1.48)\end{array}$ & $\begin{array}{l}-0.044 \\
(-1.09)\end{array}$ \\
\hline Officer termination & $\begin{array}{l}-0.031 \\
(-0.90)\end{array}$ & $\begin{array}{l}-0.033 \\
(-0.97)\end{array}$ \\
\hline Auditor termination & $\begin{array}{c}0.069 \\
(1.57)\end{array}$ & $\begin{array}{c}0.064 \\
(1.44)\end{array}$ \\
\hline Insider trading & $\begin{array}{c}0.013 \\
(0.34)\end{array}$ & $\begin{array}{c}0.008 \\
(0.22)\end{array}$ \\
\hline Settlement amount & $\begin{array}{l}-0.000293 \\
(-0.80)\end{array}$ & $\begin{array}{l}-0.000297 \\
(-0.88)\end{array}$ \\
\hline Settlement amount ${ }^{2}$ & $\begin{array}{l}2.28 \mathrm{e}-08 \\
(0.19)\end{array}$ & $\begin{array}{l}3.10 \mathrm{e}-08 \\
(0.28)\end{array}$ \\
\hline $\ln ($ market capitalization) & $\begin{array}{l}-0.0198^{*} \\
(-2.18)\end{array}$ & $\begin{array}{l}-0.0172^{+} \\
(-1.92)\end{array}$ \\
\hline Minimum return & $\begin{array}{l}-0.114 \\
(-0.90)\end{array}$ & $\begin{array}{l}-0.0820 \\
(-0.67)\end{array}$ \\
\hline Turnover & $\begin{array}{l}-0.051 \\
(-0.49)\end{array}$ & $\begin{array}{l}-0.052 \\
(-0.50)\end{array}$ \\
\hline High tech & $\begin{array}{c}0.008 \\
(0.22)\end{array}$ & $\begin{array}{l}-0.007 \\
(-0.20)\end{array}$ \\
\hline FDA & $\begin{array}{l}-0.0135 \\
(-0.13)\end{array}$ & $\begin{array}{l}0.000599 \\
(0.01)\end{array}$ \\
\hline Resolution time & $\begin{array}{l}0.0000403 \\
(1.09)\end{array}$ & $\begin{array}{l}0.0000447 \\
(1.21)\end{array}$ \\
\hline Top attorney firm & $\begin{array}{l}-0.0452 \\
(-1.29)\end{array}$ & $\begin{array}{l}-0.0609^{+} \\
(-1.79)\end{array}$ \\
\hline Constant & $\begin{array}{l}-0.823^{* *} \\
(-8.41)\end{array}$ & $\begin{array}{l}-0.823^{* *} \\
(-8.30)\end{array}$ \\
\hline$N$ & 269 & 269 \\
\hline$R^{2}$ & 0.360 & 0.399 \\
\hline
\end{tabular}

NotE: Dependent variable is $\ln$ (Atty_Fee/1 - Atty_Fee). $t$ statistics in parentheses (determined with robust standard errors); ${ }^{+} p<0.10 ; * p<0.05 ; * * p<0.01$. Independent variable definitions are found in the Appendix. 
similar to individual plaintiffs in negotiating attorney fees. The coefficient on OTHER INSTITUTION is negative and, although smaller in magnitude than state and local public pension funds, significant at the 10 percent level.

Our next test assesses the relation between assets under management and attorney fees. The intuition behind Hypothesis 1 is that larger pension funds will negotiate for lower fees. We do not have assets data for all the lead plaintiffs in our sample, so we limit our tests of this hypothesis to plaintiff types for which we are able to collect those data. As in Model 1 , we estimate an ordinary least squares model with the log odds of the requested attorney fee percentage as the dependent variable (using case-level data and robust standard errors). We use the same independent variables as in Model 1 but we replace STATE PENSION with STATE PENSION-ABOVE MEDiAn ASSETS and STATE PENSION-BELOW MEDIAN ASSETS. These variables reflect the fraction of lead plaintiffs in a case that consists of state public pensions with total fund assets at the median or above or, conversely, below the median, for state public pensions in our sample. We similarly replace the variables for LOCAL PENSION and LABOR UNION plaintiffs, dividing each by asset size in the same manner as the division for state pensions described above.

We report the results in Table 5, Model 2. For state and local pensions, larger institutions negotiate for lower attorney fees. The coefficients for the bigger state and local pension institutions are negative and significant, and they are larger than the corresponding variables for the smaller institutions. Assessed at the mean of all independent variables, a 50 percentage point increase in the fraction of lead plaintiffs that consists of STATE PENSION-ABOVE MEDIAN ASSETS funds correlates with a 5.2 percentage point decrease in the attorney fee request (or 19.7 percent of the mean requested attorney fees). Using an $F$ test to assess the difference in coefficients for large and small institutions, we find that the difference is significant at the 5 percent level for STATE PENSION and at the 1 percent level for LOCAL PENSION. Thus, it appears that larger pension funds are more effective monitors than other types of investors who serve as lead plaintiffs, which is consistent with the premise Congress adopted in enacting the PSLRA. As seen in Table 3, Panel B, larger holdings correlate with larger losses, the relevant metric for awarding lead plaintiff status. The coefficient on LABOR UNION-ABOVE MEDIAN ASSETS, however, is not significant and the difference between LABOR UNION-ABOVE MEDIAN ASSETS and LABOR UNION-BELOW MEDIAN ASSETS is also not significant.

To check the robustness of the results in Table 5, we added year and circuit effects, ${ }^{19}$ used a Heckman model to control for selection effects, ${ }^{20}$ and reestimated the models using

\footnotetext{
${ }^{19}$ We reestimated the models with the addition of year effects as well as indicator variables for those circuits with at least 30 class action settlements in our sample (the Second, Third, Fifth, Ninth, and Eleventh Circuits). Unreported, we obtained the same qualitative results as in Table 5.

${ }^{20}$ Our models focus only on those cases that were settled. To control for selection effects in our sample, we reestimated the models of Table 5 with a Heckman two-stage model (Heckman 1979). Stage 2 was the models from Table 5. Stage 1 was a model for settlement. For an instrument, we used the total number of securities class actions filed in the data set time period for the district court in which the specific class action is filed. We assume this variable is correlated with the decision to settle. A particular district court with large numbers of securities class actions may face greater pressure to dismiss such actions to clear its docket, leading to fewer settlements. On the other hand, we assume this variable
} 
robust regression to control for the possibility of outliers. ${ }^{21}$ The results are consistent with those reported in Table 5.

\section{B. Political Contributions and Attorney Fees}

\section{Size of Contribution and Attorney Fees}

Do political contributions affect the incentive of pension funds to negotiate over attorney fees? For our analysis, we focus on the CONTRIBUTION-Fund OFFICIALs measure of political contribution. We replace the STATE PENSION variables used in Model 1 of Table 5 with two variables: STATE PENSION-CONTRIBUTION and STATE PENSION-NO CONTRIBUTION.

$$
\begin{aligned}
& \ln \left(\text { Atty_Fee }_{\mathrm{i}} / 1-\text { Atty_Fee }_{\mathrm{i}}\right)=\alpha+\beta_{1 \mathrm{i}} \text { State Pension-Contribution }_{\mathrm{i}}+ \\
& \beta_{2 \mathrm{i}} \text { State Pension-No Contribution }_{\mathrm{i}}+\beta_{3 \mathrm{i}} \text { Local Pension }_{\mathrm{i}}+\beta_{4 \mathrm{i}}{\text { Labor } \text { Union }_{\mathrm{i}}+}+ \\
& \beta_{5 \mathrm{i}} \text { Other Institution }_{\mathrm{i}}+\text { Case Controls }+\varepsilon_{\mathrm{i}}
\end{aligned}
$$

Model 1 of Table 6 reports our results. We find evidence that state pension funds whose officials have received campaign contributions from class action attorneys correlate with higher fees than state pensions funds whose officials have not received contributions. The coefficients for STATE PENSION-CONTRIBUTION and STATE PENSION-NO CONTRIBUTION are both negative and significant at the 1 percent level. The magnitude of the state

is not correlated directly with requested attorney fees in a particular settled litigation. Unreported, in the Heckman version of Model 1, STATE PENSION remains negative and significant at the 1 percent level. LocAL PENSION, while negative, is significant now at the 5 percent level. OTHER INSTITUTION is not significant. In the Heckman version of Model 2, we obtained the same qualitative results.

Other possible selection effects include the decision to file suit; we only observe cases that are filed. If the decision to file a suit is correlated with the relationship between lead plaintiff composition and selection and attorney agency costs, then our results may be biased. Nonetheless, in an analysis of case outcomes (high value settlement vs. nuisance-level settlements or dismissal), Choi (2011) reports no qualitative change in his results when controlling for the decision-to-file selection effect. Plaintiffs' attorneys also have a choice of forum. Cox et al. (2008), however, report that most forum-selection decisions are largely driven by geographical convenience (a factor relevant to venue determinations) and are thus unlikely to be correlated with the variables of interest in our analysis.

It is also possible that public pension funds may tend to select larger law firms. If larger law firms both: (1) charge higher fees and are more profitable and (2) make greater political contributions because of their greater profits, then correlations between contributions and higher attorney fees may not follow from a direct causal relationship between contributions and fees. We lack an instrument to assess this possible selection effect. Nonetheless, the coefficient on TOP ATTORNEY FIRM in both models of Table 5 is negative (and significant at the 10 percent level in Model 2), indicating that larger law firms, if anything, correlate with lower, not higher, fees, all else equal. In addition, we determined that among all public pension funds in our sample, 49.5 percent associated with TOP ATTORNEY FIRM, while the nonpublic pension fund lead plaintiffs associated with a TOP ATTORNEY FIRM as lead counsel 58.2 percent of the time. Similarly, state public pension funds associated with a TOP ATTORNEY FIRM lead counsel 32.7 percent of the time, while all other lead plaintiffs associated with a TOP ATTORNEY FIRM 58.8 percent of the time. We therefore find no evidence that state public pension funds have an increased propensity to associate with the largest (and hypothetically most profitable) plaintiffs' attorney law firms.

\footnotetext{
${ }^{21}$ We obtained similar qualitative results when we reestimated the models in Table 5 using robust regression, with the following differences. In Model 1 , the coefficient on OTHER InSTITUTION is negative and now significant at the 5 percent level. In Model 2, the coefficient on LABOR UNION-ABOVE MEDIAN ASSETS is negative and now significant at the 10 percent level; the difference between ABOVE MEDIAN ASSETS and BELOW MEDIAN ASSETS for LABOR UNION, however, remains insignificant.
} 
Table 6: Campaign Contributions and Attorney Fees

\begin{tabular}{|c|c|c|c|}
\hline & Model 1 & Model 2 & Model 3 \\
\hline State pension-contribution & $\begin{array}{l}-0.325^{* *} \\
(-3.64)\end{array}$ & & \\
\hline State pension-large contribution & & $\begin{array}{c}-0.026 \\
(-0.15)\end{array}$ & \\
\hline State pension-small contribution & & $\begin{array}{l}-0.379 * * \\
(-3.83)\end{array}$ & \\
\hline State pension-no contribution & $\begin{array}{l}-0.546^{* *} \\
(-5.11)\end{array}$ & $\begin{array}{l}-0.539 * * \\
(-5.02)\end{array}$ & \\
\hline State pension-large contribution all state officials & & & $\begin{array}{r}0.060 \\
(0.53)\end{array}$ \\
\hline State pension-small contribution all state officials & & & $\begin{array}{l}-0.483^{* *} \\
(-4.88)\end{array}$ \\
\hline State pension-no contribution all state officials & & & $\begin{array}{l}-0.564^{* *} \\
(-3.99)\end{array}$ \\
\hline Local pension & $\begin{array}{l}-0.287 * * \\
(-3.16)\end{array}$ & $\begin{array}{l}-0.282^{* *} \\
(-3.15)\end{array}$ & $\begin{array}{l}-0.262^{* * *} \\
(-3.01)\end{array}$ \\
\hline Labor union & $\begin{array}{c}-0.018 \\
(-0.37)\end{array}$ & $\begin{array}{l}-0.018 \\
(-0.36)\end{array}$ & $\begin{array}{l}-0.017 \\
(-0.34)\end{array}$ \\
\hline Other institution & $\begin{array}{l}-0.100^{+} \\
(-1.74)\end{array}$ & $\begin{array}{c}-0.097^{+} \\
(-1.68)\end{array}$ & $\begin{array}{c}-0.097^{+} \\
(-1.68)\end{array}$ \\
\hline Constant & $\begin{array}{l}-0.830 * * \\
(-8.65)\end{array}$ & $\begin{array}{l}-0.829 * * \\
(-8.61)\end{array}$ & $\begin{array}{l}-0.814^{* *} \\
(-8.35)\end{array}$ \\
\hline Case controls & Yes & Yes & Yes \\
\hline$N$ & 269 & 269 & 269 \\
\hline$R^{2}$ & 0.367 & 0.371 & 0.379 \\
\hline
\end{tabular}

Note: Dependent variable is $\ln$ (Atty_Fee/1 - Atty_Fee). $t$ statistics in parentheses (determined with robust standard errors) $;{ }^{+} p<0.10 ; *<0.05 ; * * p<0.01$. Independent variables definitions are in the Appendix. Case controls include the Section 11, Section 14, gov't investigation, restatement, officer term., auditor term., insider trading claim, settlement amount, settlement amount ${ }^{2}, \ln$ (market capitalization), turnover, minimum return, high tech, FDA, resolution time, and top attorney firm variables.

PENSION-NO CONTRIBUTION is greater than STATE PENSION-CONTRIBUTION, indicating higher attorney fees when officials received a contribution from the attorneys. Assessed at the mean of all independent variables, a 50 percentage point increase in the fraction of lead plaintiffs that consists of STATE PENSION-CONTRIBUTION funds correlates with a 3.0 percentage point decrease in the attorney fee request (or 11.4 percent of the mean requested attorney fees). In comparison, a 50 percentage point increase in the fraction of lead plaintiffs that consists of STATE PENSION-NO CONTRIBUTION funds correlates with a 4.9 percentage point decrease in the attorney fee request (or 18.6 percent of the mean requested attorney fees). An $F$ test reveals that the difference is significant at the 10 percent level, supporting Hypothesis 2.

We also test whether the size of the contribution matters. We divide the sTATE PENSION-CONTRIBUtion variable in Model 1 of Table 6 into two categories. STATE PENSIONLARGE CONTRIBUTION is the fraction of lead plaintiffs in a case that consists of state pension funds that received a contribution from the lead attorneys of greater than $\$ 10,000$ (the median contribution amount in our sample) during our four-year window around the suit 
filing; STATE PENSION-SMALL CONTRIBUTION is the fraction of lead plaintiffs that consists of state pension funds that received contribution of $\$ 10,000$ or less.

The results from this regression are reported as Model 2 of Table 6 . Here we find that the coefficient for STATE PENSION-LARGE CONTRIBUTION is not significantly different from zero. This lack of significance may reflect the small number of state pension funds receiving large contributions. The coefficient for STATE PENSION-SMALL CONTRIBUTION, however, is negative and significant at the 1 percent level. More importantly, the difference between the two coefficients is significant at the 10 percent level; the small numbers in these categories bias against finding any significant difference between the two coefficients. Assessed at the mean of all independent variables, a 50 percentage point increase in the fraction of lead plaintiffs that consists of STATE PENSION-SMALL CONTRIBUTION funds correlates with a 3.5 percentage point decrease in the attorney fee request (or 13.2 percent of the mean requested attorney fees). These findings, consistent with Hypothesis 3, suggest that larger campaign contributions temper the zeal of state pension funds to squeeze lower fees out of their attorneys.

In Model 3 of Table 6, we replace the contribution variables in Model 2 with the broader CONTRIBUTION-ALL STATE OFFICIALS measure defined above (generating STATE PENSION-LARGE CONTRIBUTION ALL STATE OFFICIALS, STATE PENSION-SMALL CONTRIBUTION ALL STATE OFFICIALS, and STATE PENSION-NO CONTRIBUTION ALL STATE OFFICIALS variables). The CONTRIBUTION-ALL STATE OfFicials measure allows us to assess whether the benefit plaintiffs' attorneys obtain from political contributions depends not only on direct contributions to fund officials, but also on contributions more generally in the state. Because the aggregate amounts in our CONTRIBUTION-ALL STATE OFFICIALS measure are larger than the contributions only to fund officials, we use $\$ 100,000$ as our cutoff to divide large and small contribution amounts. We obtain similar results in Model 3 as in Model 2 of Table 6. The coefficient for state pension-Large contribution all state OFFICIALS is positive although small in magnitude and insignificant. The coefficient for STATE PENSION-SMALL CONTRIBUTION ALL STATE OFFICIALS is negative and significant at the 1 percent level, and the difference between the two coefficients is significant at the 1 percent level.

To check the robustness of the models in Table 6 , we substituted a linear measure of contribution size, ${ }^{22}$ added year and circuit effects, ${ }^{23}$ used a Heckman model to

\footnotetext{
${ }^{22}$ Instead of distinguishing between those state pensions that received above the median contributions and those that received median or below contributions, we reestimated Model 2 of Table 6 replacing STATE PENSION-LARGE CONTRIBUTION, STATE PENSION-SMALl CONTRIBUTION, and STATE PENSION-NO CONTRIBUTION with the actual amount of the contributions paid to state fund officials or politicians associated with fund officials (STATE PENSIONCONTRIBUTION AMOUNT) and the square of STATE PENSION-CONTRIBUTION AMOUNT and obtained similar qualitative results. Unreported, the coefficient on STATE PENSION-CONTRIBUTION AMOUNT is negative and significant at the 1 percent level; the coefficient on the square of STATE PENSION-CONTRIBUTION AMOUNT is positive and significant at the 1 percent level. These results are consistent with the view that political contributions correlate with higher attorney fees, particularly at higher levels of political contributions.
}

\footnotetext{
${ }^{23}$ We reestimated the models of Table 6 with the addition of year effects as well as indicator variables for those circuits with at least 30 class action settlements in our sample (the Second, Third, Fifth, Ninth, and Eleventh Circuits). We obtained the same qualitative results as in Table 6 for Models 1 and 3. In Model 2, the difference between STATE
} 
control for selection effects, ${ }^{24}$ reestimated the models using robust regression to control for the possibility of outliers, ${ }^{25}$ and reestimated the models only for cases that involved at least one institutional investor lead plaintiff. ${ }^{26}$ The results are consistent with those reported in Table 6. We also reestimated Model 2 of Table 6 with an alternate definition for a large contribution (based on the size of the contribution relative to the average size of contribution to governor candidates) and obtained similar qualitative results. ${ }^{27}$

PENSION-LARGE CONTRIBUTION and STATE PENSION-SMALL CONTRIBUTION is beyond conventional levels of statistical significance (at the 13.4 percent level), weakening the support for Hypothesis 3.

${ }^{24}$ To control for selection effects, we reestimated the models of Table 6 with a Heckman two-stage model (Heckman 1979). Stage 2 was the models from Table 6. Stage 1 was a model for settlement. For an instrument, we used the total number of securities class actions filed in the data set time period for the district court in which the specific class action is filed. Unreported, in the Heckman version of Model 1, the difference in the coefficients for STATE PENSION-CONTRIBUTION and STATE PENSION-NO CONTRIBUTION is significant at only the 10.6 percent level, weakening the support for Hypothesis 2. In the Heckman version of Model 2, the difference between STATE PENSION-LARGE CONTRIBUTION and STATE PENSION-SMALL CONTRIBUTION in Model 2 is no longer significant, weakening the support for Hypothesis 3. In the Heckman version of Model 3, the difference between STATE PENSION-LARGE CONTRIBUTION ALL STATE OFFICIALS and STATE PENSION-SMALL CONTRIBUTION ALL STATE OFFICIALS is significant at the 10 percent level.

${ }^{25}$ We obtained similar, but not identical, qualitative results when we reestimated the models in Table 6 using robust regression. Unreported, in the Heckman version of Model 1, the difference in the coefficients for STATE PENSION-CONTRIBUTION and STATE PENSION-NO CONTRIBUTION is now significant at the 5 percent level, strengthening the support for Hypothesis 2. In the Heckman version of Model 2, the difference between STATE PENSIONLARGE CONTRIBUtion and STATE PENSION-SMALl CONTRIbUtion in Model 2 is no longer significant, weakening the support for Hypothesis 3. In the Heckman version of Model 3, the difference between STATE PENSION-LARGE CONTRIBUTION ALL STATE OFFICIALS and STATE PENSION-SMALL CONTRIBUTION ALL STATE OFFICIALS is significant at the 1 percent level.

${ }^{26}$ Cases where only individuals serve as lead plaintiffs may systematically differ from cases where institutional investors serve as lead plaintiffs. Cases with only individual lead plaintiffs often involve smaller potential damages and fewer competing motions for lead plaintiffs (and lead counsel). The fewer competing motions for lead plaintiffs and lead counsel, in turn, will likely bias the attorney fees for individual-only lead plaintiff cases to be higher than for cases involving at least one institutional investor lead plaintiff, all else equal. As a robustness test, we reestimated the models in Table 6 only for cases with at least one institutional investor lead plaintiff. Unreported, we obtained similar qualitative results as in Table 6 with the following differences. The difference between STATE PENSION-CONTRIBUTION and STATE PENSION-NO CONTRIBUTION is now significant at the 5 percent level in Model 1. In contrast, the difference between STATE PENSION-LARGE CONTRIBUTION and STATE PENSION-SMALL CONTRIBUTION is now significant at only the 20.1 percent level in Model 2, beyond conventional levels of statistical significance.

${ }^{27}$ We reestimated Model 2 of Table 6 using contributions above $\$ 15,000$ to fund officials. In selecting the $\$ 15,000$ threshold, we computed the average contribution amount from all donors for 2003 to 2006 to governor candidates in each state as tracked by followthemoney.org. We computed the average contribution amount by first averaging the state mean contribution amounts for the 2003 to 2006 years separately. We then computed the mean across the four years to give the overall average contribution amount. Our cutoff threshold for large contributions of $\$ 15,000$ represents a little more than 10 times the average contribution amount from all donors of $\$ 1,426$ (and also represents roughly the top quintile of the contributions received by state pension fund officials in our data set). We posit that for campaign contributions to be influential, they have to be substantially greater than the average. Unreported, as in Model 2, the coefficient on STATE PENSION-LARGE CONTRIBUtion is small in magnitude and not significant while the coefficient on STATE PENSION-SMALl CONTRIBUtion is negative and significant at the 1 percent level. Similar to the 


\section{Fund Asset Size and Contributions}

Our next set of tests assesses the effect that attorney campaign contributions might have on attorney fees negotiated by larger state pension funds, we divide the STATE PENSION-ABOVE MEDian ASSETS variable used in Table 5, Model 2 into the following two variables. STATE PENSION-ABOVE MEDIAN ASSETS CONTRIBUTION is the fraction of lead plaintiffs in a case that consists of state pension funds that received a contribution from one of the lead attorneys and that had total fund assets at the median or above for state pension funds in our sample, and STATE PENSION-ABOve MEDian ASSETS NO CONTRIBUtion is the fraction of those funds that did not receive a contribution.

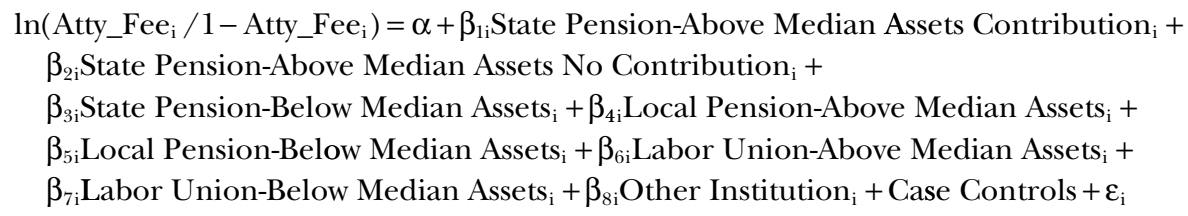

We report the results as Model 1 in Table 7. The results are similar to those reported in Model 2 of Table 5. The coefficients for STATE PENSION-Above MEdian ASSETS CONTRIBUTION and STATE PENSION-ABOVE MEDIAN ASSETS NO CONTRIBUTION are both negative and strongly significant. The magnitude of the coefficient for STATE PENSION-ABOVE MEDIAN ASSETS CONTRIBUTION is nonetheless greater than the coefficient for state PENSION-ABOVE MEDian assets no CONTRibution. The difference between the two coefficients is significant at the 1 percent level, indicating that larger funds that received contributions pay higher attorney fees than larger funds that do not receive contributions. This finding supports Hypothesis 2 with respect to funds with greater assets.

In Model 2 of Table 7, we divide state PEnsion-Above MEdian ASSETS CONTRIBUTION into two categories based on the size of contributions received by fund officials, following the method described with respect to Table 6, Model 2 (defining large as over $\$ 10,000$, the median contribution amount). When we estimate this regression, we find that larger state pension funds that have received large contributions (STATE PENSIONABOVE MEDIAN ASSETS LARGE CONTRIBUtion) are statistically indistinguishable from

results in Model 2, the difference between the coefficients for STATE PENSION-LARGE CONTRIbUtion and STATE PENSION-SMALL CONTRIBUTION is significant at the 5 percent level.

We use the requested attorney fee as our measure of agency costs between the plaintiffs' attorneys and the class. We lack data on the granted fee for many of our cases. For those cases where we have data, the granted fee is highly correlated with the requested fee (correlation coefficient $=0.877$ ). As a robustness test, we reestimated the models in Table 6 using the log odds of the granted fee as a percentage of the settlement amount as the dependent variable. Unreported, we obtained similar qualitative results as in Table 6 with the following differences. The difference between STATE PENSION-CONTRIBUTION and STATE PENSION-NO CONTRIBUTION is now significant at the 1 percent level in Model 1. In contrast, the difference between STATE PENSION-LARGE CONTRIBUTION and STATE PENSION-SMALL CONTRIBUtion is now significant at only the 17.5 percent level in Model 2, beyond conventional levels of statistical significance. 
Table 7: Pension Fund Assets and Attorney Fees

\begin{tabular}{|c|c|c|}
\hline & Model 1 & Model 2 \\
\hline State pension-above median assets contribution & $\begin{array}{l}-0.367 * * \\
(-3.86)\end{array}$ & \\
\hline State pension-above median assets large contribution & & $\begin{array}{c}-0.021 \\
(-0.11)\end{array}$ \\
\hline State pension-above median assets small contribution & & $\begin{array}{l}-0.432^{* *} \\
(-4.48)\end{array}$ \\
\hline State pension-above median assets no contribution & $\begin{array}{l}-0.776^{* *} \\
(-8.37)\end{array}$ & $\begin{array}{l}-0.767^{* *} \\
(-8.09)\end{array}$ \\
\hline State pension-below median assets & $\begin{array}{l}-0.245^{*} \\
(-1.97)\end{array}$ & $\begin{array}{c}-0.237^{+} \\
(-1.85)\end{array}$ \\
\hline Local pension-above median assets & $\begin{array}{l}-0.571^{* *} \\
(-3.70)\end{array}$ & $\begin{array}{l}-0.566^{* * *} \\
(-3.77)\end{array}$ \\
\hline Local pension-below median assets & $\begin{array}{l}-0.075 \\
(-1.05)\end{array}$ & $\begin{array}{c}-0.072 \\
(-1.00)\end{array}$ \\
\hline Labor union-above median assets & $\begin{array}{c}-0.038 \\
(-0.61)\end{array}$ & $\begin{array}{c}-0.037 \\
(-0.58)\end{array}$ \\
\hline Labor union-below median assets & $\begin{array}{l}-0.004 \\
(-0.06)\end{array}$ & $\begin{array}{c}-0.003 \\
(-0.05)\end{array}$ \\
\hline Other institution & $\begin{array}{l}-0.103^{+} \\
(-1.81)\end{array}$ & $\begin{array}{l}-0.100^{+} \\
(-1.74)\end{array}$ \\
\hline Constant & $\begin{array}{l}-0.856^{* * *} \\
(-8.73)\end{array}$ & $\begin{array}{l}-0.857^{* *} \\
(-8.70)\end{array}$ \\
\hline Case controls & Yes & Yes \\
\hline$N$ & 269 & 269 \\
\hline$R^{2}$ & 0.414 & 0.418 \\
\hline
\end{tabular}

Note: Dependent variable is $\ln$ (Atty_Fee/1-Atty_Fee). $t$ statistics in parentheses (determined with robust standard errors) $;{ }^{+} p<0.10 ; *<0.05 ; * * p<0.01$. Independent variables definitions are in the Appendix. Case controls include the Section 11, Section 14, gov't investigation, restatement, officer term., auditor term., insider trading claim, settlement amount, settlement amount ${ }^{2}, \ln$ (market capitalization), turnover, minimum return, high tech, FDA, resolution time, and top attorney firm variables.

individual lead plaintiffs when it comes to negotiating attorney fees. In contrast, the coefficient on STATE PENSION-ABOVE MEDIAN ASSETS SMALL CONTRIBUTION is negative and significant at the 1 percent level; the difference between the two coefficients is significant at the 5 percent level. Assessed at the mean of all independent variables, a 50 percentage point increase in the fraction of lead plaintiffs that consists of STATE PENSION-ABOvE MEDiAN ASSETS SMALL CONTRIBUTION funds correlates with a 3.9 percentage point decrease in the attorney fee request (or 15.0 percent of the mean requested attorney fees); in contrast, a 50 percentage point increase in the fraction of lead plaintiffs that consists of STATE PENSION-ABOVE MEDIAN ASSETS LARGE CONTRIBUTION funds correlates with a 0.2 percentage point decrease in the attorney fee request (or 0.7 percent of the mean requested attorney fees). We conclude that greater state public pension size does correlate with greater monitoring of plaintiffs' attorneys, but that the effect is neutered if the state public pension officials have received substantial contributions from the lead attorneys. 
To check the robustness of the results in Table 7, we added year and circuit effects, ${ }^{28}$ used a Heckman model to control for selection effects, ${ }^{29}$ reestimated the models using robust regression to control for the possibility of outliers,,$^{30}$ and reestimated the models only for cases that involved at least one institutional investor lead plaintiff. ${ }^{31}$ The results are generally consistent with those reported in Table 7 .

\section{Fund Losses and Contributions}

Bigger pension funds may have more leverage in negotiating with the class attorney, but it is also possible that greater losses will give a pension fund a heightened incentive to negotiate. If losses are substantial enough, the size of the attorney fee is likely to make a material difference to the pension fund's recovery. To assess this possibility, we substitute two new variables, STATE PENSION-LARGE LOSSES and STATE PENSION-SMALL LOSSES, for the state pension variable used in the regressions presented in Table 5, Model 1. State PENSION-LARGE LOSSES is defined as a pension fund with a claim over $\$ 1$ million in a given case; small losses are $\$ 1$ million or lower.

$$
\begin{gathered}
\ln \left(\text { Atty_Fee }_{\mathrm{i}} / 1-\text { Atty_Fee }_{\mathrm{i}}\right)=\alpha+\beta_{1 \mathrm{i}} \text { State Pension-Large Losses }_{\mathrm{i}}+ \\
\beta_{2 \mathrm{i}} \text { State Pension-Small Losses }_{\mathrm{i}}+\beta_{3 \mathrm{i}} \text { Local Pension }_{\mathrm{i}}+ \\
\beta_{4 \mathrm{i}} \text { Labor Union }_{\mathrm{i}}+\beta_{5 \mathrm{i}} \text { Other Institution }_{\mathrm{i}}+\text { Case Controls }+\varepsilon_{\mathrm{i}}
\end{gathered}
$$

The results are presented in Table 8, Model 1 . We find that the coefficients for STATE PENSION-LARGE LOSSES is negative and significant (at the 5 percent level). The coefficient for STATE PENSION-SMALl LOSSES, while negative, is smaller in magnitude and significant at only the 10 percent level, indicating that funds with a lower stake in the litigation may not

\footnotetext{
${ }^{28}$ We reestimated the models of Table 7 with the addition of year effects as well as indicator variables for those circuits with at least 30 class action settlements in our sample (the Second, Third, Fifth, Ninth, and Eleventh Circuits). Unreported, we obtained the same qualitative results with one difference. In Model 2, the difference between coefficients for STATE PENSION-ABOVE MEDIAN ASSETS LARGE CONTRIBUTION and STATE PENSION-ABOVE MEDIAN ASSETS SMALl CONTRIBUtion is now significant at the 5.04 percent level, still consistent with Hypothesis 3 .
}

\footnotetext{
${ }^{29}$ To control for selection effects, we reestimated the models of Table 7 with a Heckman two-stage model (Heckman 1979). Stage 2 was the models from Table 7. Stage 1 was a model for settlement. For an instrument, we used the total number of securities class actions filed in the data set time period for the district court in which the specific class action is filed. Unreported, the Heckman models returned the same qualitative results as in Table 7 with two differences. In Model 1, the difference between coefficients for STATE PENSION-ABOVE MEDIAN ASSETS CONTRIBUTION and STATE PENSION-ABOVE MEDIAN ASSETS NO CONTRIBUTION is now significant at the 10 percent level, still consistent with Hypothesis 2. In Model 2, in contrast, the difference between STATE PENSION-Above MEdian ASSETS LARGE CONTRIBUTION and STATE PENSION-ABOVE MEDIAN ASSETS SMALL CONTRIBUTION is no longer statistically significant, weakening the support for Hypothesis 3 .
}

\footnotetext{
${ }^{30} \mathrm{We}$ obtained similar qualitative results when we reestimated the models in Table 7 using robust regression with the following one difference. In Model 2, the difference between the coefficients for STATE PENSION-ABOvE MEDIAN ASSETS LARGE CONTRIBUTION and STATE PENSION-ABOVE MEDIAN ASSETS SMALL CONTRIBUTION is now significant at the 10 percent level, still consistent with Hypothesis 2.
}

${ }^{31}$ Unreported, we obtained similar qualitative results as in Table 7. 
Table 8: Pension Losses and Attorney Fees

\begin{tabular}{lcc}
\hline & Model 1 & Model 2 \\
\hline State pension-large losses & $-0.285^{*}$ & \\
State pension-large losses contribution & $(-2.04)$ & 0.206 \\
& & $(1.57)$ \\
State pension-large losses no contribution & & $-0.418^{* *}$ \\
State pension-small losses & & $(-3.31)$ \\
& $-0.165^{+}$ & $-0.169^{+}$ \\
Local pension & $(-1.90)$ & $(-1.94)$ \\
& $-0.259^{* *}$ & $-0.244^{* *}$ \\
Labor union & $(-2.77)$ & $(-2.66)$ \\
& 0.025 & 0.031 \\
Other institution & $(0.48)$ & $(0.58)$ \\
& -0.048 & -0.044 \\
Constant & $(-0.81)$ & $(-0.75)$ \\
Case controls & $-0.770^{* *}$ & $-0.765^{* *}$ \\
$N$ & $(-6.93)$ & $(-7.02)$ \\
$R^{2}$ & Yes & Yes \\
\end{tabular}

Note: Dependent variable is $\ln$ (Atty_Fee/1-Atty_Fee). $t$ statistics in parentheses (determined with robust standard errors) $;{ }^{+} p<0.10 ; * p<0.05 ; * *<<0.01$. Independent variables definitions are in the Appendix. Case controls include the Section 11, Section 14, gov't investigation, restatement, officer term., auditor term., insider trading claim, settlement amount, settlement amount ${ }^{2}, \ln$ (market capitalization), turnover, minimum return, high tech, FDA, resolution time, and top attorney firm variables.

negotiate as vigorously on behalf of the class with the attorneys. An $F$ test, however, reveals that the difference between the two coefficients is not significant. Thus, this regression does not support the hypothesis that greater losses lead to more monitoring by state pension funds. ${ }^{32}$

It is possible, however, that the incentive for monitoring created by larger losses might be undermined by campaign contributions. To test this possibility we split STATE PENSION-LARGE LOSSES into tWO variables: STATE PENSION-LARGE LOSSES CONTRIBUTION and STATE PENSION-LARGE LOSSES NO CONTRIBUTION. The other variables are the same as Model 1 of Table 8.

The results for this regression are presented as Model 2 in Table 8. We find that the coefficient for STATE PENSION-LARGE LOSSES CONTRIBUTION is positive, but insignificant. By contrast, the coefficient for STATE PENSION-LARGE LOSSES NO CONTRIBUTION is negative and significant at the 1 percent level. Assessed at the mean of all independent variables, a 50 percentage point increase in the fraction of lead plaintiffs that consists of STATE PENSION-LARGE LOSSES NO CONTRIBUTION funds correlates with a 3.8 percentage point decrease in the attorney fee request (or 14.5 percent of the mean requested

\footnotetext{
${ }^{32}$ In contrast, Choi (2011) reports that lower losses across the set of all lead plaintiff types correlates significantly with higher attorney fees.
} 
attorney fees); in contrast, a 50 percentage point increase in the fraction of lead plaintiffs that consists of STATE PENSION-LARGE LOSSES CONTRIBUTION funds correlates with a 2.0 percentage point increase in the attorney fee request (or 7.7 percent of the mean requested attorney fees). The $F$ test assessing the difference between the two coefficients is significant at the 1 percent level, supporting the view that campaign contributions undermined the incentive of pension funds with large losses to negotiate for lower attorney fees.

To check the robustness of the results in Table 8, we added year and circuit effects, ${ }^{33}$ used a Heckman model to control for selection effects, ${ }^{34}$ reestimated the models using robust regression to control for the possibility of outliers, ${ }^{35}$ and reestimated the models only for cases that involved at least one institutional investor lead plaintiff. ${ }^{36}$ The results largely remained consistent with those reported in Table 8 . We also reestimated the models in Table 8 using losses above $\$ 10$ million as an alternate definition for large losses and obtained similar qualitative results.

\title{
C. State Receptivity to Contributions
}

We postulated with Hypothesis 4 that the pervasiveness of the conflict created by campaign contributions might influence attorney fees. To test this possibility, we identified the state pension funds that appeared at least twice in our sample. For these funds, we then identified the law firm that had represented the fund most frequently for the cases in our sample and determined the fraction of those cases in which the law firm had represented the fund. Based on this fraction, we create an indicator variable, FREQUENT ATTORNEY, equal to 1 if the law firm represented the pension fund in over 75 percent of the cases in which the pension fund appeared; 0 otherwise. For our main independent variables of interest we

\footnotetext{
${ }^{33}$ We reestimated the models of Table 8 with the addition of year effects as well as indicator variables for those circuits with at least 30 class action settlements in our sample (the Second, Third, Fifth, Ninth, and Eleventh Circuits). Unreported, we obtained similar qualitative results. The coefficient in Model 1 on STATE PENSION-SMALL LOSSES is negative and now significant at the 1 percent level; the difference between STATE PENSION-LARGE LOSSES and STATE PENSION-SMALL LOSSES remains not significantly different from zero. In Model 2, the difference in the coefficients for STATE PENSION-LARGE LOSSES CONTRIBUTION and STATE PENSION-LARGE LOSSES NO CONTRIBUTION remains significant at the 1 percent level.
}

\begin{abstract}
${ }^{34}$ To control for selection effects, we reestimated the models of Table 8 with a Heckman two-stage model (Heckman 1979). Stage 2 was the models from Table 8. Stage 1 was a model for settlement. For an instrument, we used the total number of securities class actions filed in the data set time period for the district court in which the specific class action is filed. Unreported, the Heckman models returned the same qualitative results as in Table 8. In the Heckman version of Model 2, the difference in the coefficients for STATE PENSION-LARGE LOSSES CONTRIBUtion and STATE PENSION-LARGE LOSSES NO CONTRIBUTION is now significant at only the 5 percent level.
\end{abstract}

\footnotetext{
${ }^{35} \mathrm{We}$ obtained similar qualitative results when we reestimated the models in Table 8 using robust regression. The coefficient in Model 1 on STATE PENSiON-SMall losses is negative and now insignificant; the difference between STATE PENSION-LARGE LOSSES and STATE PENSION-SMALl LOSSES remains not significantly different from zero. In Model 2, the difference in the coefficients for STATE PENSION-LARGE LOSSES CONTRIBUTION and STATE PENSION-LARGE LOSSES NO CONTRIBUTION remains significant at the 1 percent level.
}

${ }^{36}$ Unreported, we obtained similar qualitative results as in Table 8. 
Table 9: State Receptivity to Contributions

\begin{tabular}{lcc}
\hline & Model 1 & Model 2 \\
\hline State pension-frequent attorney & $-0.273^{*}$ & $(-2.11)$ \\
State pension-frequent attorney contribution & & -0.043 \\
& & $(-0.57)$ \\
State pension-frequent attorney no contribution & $-0.328^{*}$ \\
State pension-infrequent attorney & $(-2.28)$ \\
& & $-0.575^{* *}$ \\
Local pension & $-0.581^{* *}$ & $(-5.73)$ \\
& $(-5.81)$ & $-0.274^{* *}$ \\
Labor union & $-0.278^{* *}$ & $(-3.06)$ \\
& $(-3.11)$ & -0.026 \\
Other institution & -0.029 & $(-0.54)$ \\
Constant & $(-0.59)$ & $-0.106^{+}$ \\
Case controls & $-0.106^{+}$ & $(-1.83)$ \\
$N$ & $(-1.85)$ & $-0.834^{* *}$ \\
$R^{2}$ & $-0.843^{* *}$ & $(-8.47)$ \\
\end{tabular}

Note: Dependent variable is $\ln$ (Atty_Fee/1-Atty_Fee). $t$ statistics in parentheses (determined with robust standard errors) $;{ }^{+} p<0.10 ; * p<0.05 ; * *<<0.01$. Independent variables definitions are in the Appendix. Case controls include the Section 11, Section 14, gov't investigation, restatement, officer term., auditor term., insider trading claim, settlement amount, settlement amount ${ }^{2}, \ln$ (market capitalization), turnover, minimum return, high tech, FDA, resolution time, and top attorney firm variables.

then define STATE PENSION-FREQUENT ATTORNEY as the fraction of lead plaintiffs in a case that consists of state pension funds with a frequent attorney. We define state PENSIONINFREQUENT ATTORNEY as the fraction of lead plaintiffs in a case that consists of state pension funds not represented by a frequent attorney.

Using these variables, we again estimate an ordinary least squares model with the log odds of the requested attorney fee percentage as the dependent variable (using case-level data and robust standard errors). The other independent variables are the same as those used in the regressions presented in Table 5.

$$
\begin{aligned}
& \ln \left(\text { Atty_Fee }_{\mathrm{i}} / 1-\text { Atty_Fee }_{\mathrm{i}}\right)=\alpha+\beta_{1 \mathrm{i}} \text { State Pension-Frequent Attorney }_{\mathrm{i}}+ \\
& \beta_{2 \mathrm{i}} \text { StatePension-Infrequent Attorney }_{\mathrm{i}}+\beta_{3 \mathrm{i}} \text { Local Pension }_{\mathrm{i}}+\beta_{4 \mathrm{i}} \text { Labor Union }_{\mathrm{i}}+
\end{aligned}
$$

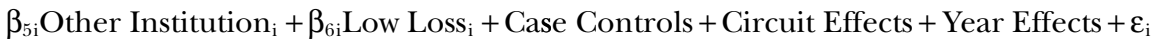

We present the results in Model 1 of Table 9. The coefficients for both sTate PENSION-FREQUENT ATTORNEY and STATE PENSION-INFREQUENT ATTORNEY are negative and significant at the 5 percent and 1 percent levels, respectively. The magnitude of state PENSION-INFREQUENT ATTORNEY, however, is considerably larger, indicating lower attorney fees. Moreover, an $F$ test confirms that the coefficient for funds represented by a frequent attorney is significantly different (at the 5 percent level) from the coefficient for infrequent attorney. 
Frequent representation is ambiguous: it could signal satisfaction with the quality of legal representation, or it could signal satisfaction with the level of campaign contributions being received. To distinguish between these two possibilities, we replace the state PENSION-FREQUENT ATTORNEY variable with the following two variables. We define STATE PENSION-FREQUENT ATTORNEY CONTRIBUTION as the fraction of lead plaintiffs in a case that consists of state public pensions with a frequent attorney and where the attorney firm made contributions to state pension fund officials in the four-year window surrounding the date of suit filing, and STATE PENSION-FREQUENT ATTORNEY NO CONTRIBUTION as the fraction of lead plaintiffs in a case that consists of state public pensions that have a frequent attorney, but have not taken campaign contributions in the four-year window surrounding the date of suit filing.

We present the results as Model 2 of Table 9. As with our earlier regressions, controlling for contribution makes an important difference to the regression results. Recipients of contributions from a frequent attorney pay significantly higher attorney fees than do pension funds with a frequent representation but that have not received campaign contributions. The coefficient for STATE PENSION-FREQUENT ATTORNEY CONTRIBUTION is insignificant, suggesting that such pension funds negotiate fees similar to those negotiated by individual plaintiffs. The coefficient for STATE PENSION-FREQUENT ATTORNEY NO CONTRIBUTION is negative and significant at the 5 percent level. The difference between the two coefficients is significant at the 10 percent level. Assessed at the mean of all independent variables, a 50 percentage point increase in the fraction of lead plaintiffs that consists of STATE PENSION-FREQUENT ATTORNEY NO CONTRIBUTION correlates with a 3.0 percentage point decrease in the attorney fee request (or 11.5 percent of the mean requested attorney fees); in contrast, a 50 percentage point increase in the fraction of lead plaintiffs that consists of STATE PENSION-FREQUENT ATTORNEY CONTRIBUTION funds correlates with only a 0.4 percentage point decrease in the attorney fee request (or 1.6 percent of the mean requested attorney fees). In sum, it appears that the funds relying primarily on one law firm provide very little monitoring of attorney fees if they have received campaign contributions from that firm.

To check the robustness of the results in Table 9, we added year and circuit effects, ${ }^{37}$ used a Heckman model to control for selection effects, ${ }^{38}$ reestimated the models using

\footnotetext{
${ }^{37}$ We reestimated the models with the addition of year effects as well as indicator variables for those circuits with at least 30 class action settlements in our sample (the Second, Third, Fifth, Ninth, and Eleventh Circuits). Unreported, we obtained the same qualitative results with one difference. In Model 2, the difference between STATE PENSIONFREQUENT ATTORNEY CONTRIBUTION and STATE PENSION-FREQUENT ATTORNEY NO CONTRIBUTION is now significant at the 1 percent level.

${ }^{38}$ To control for selection effects, we reestimated the models of Table 9 with a Heckman two-stage model (Heckman 1979). Stage 2 was the models from Table 9. Stage 1 was a model for settlement. For an instrument, we used the total number of securities class actions filed in the data set time period for the district court in which the specific class action is filed. Unreported, the Heckman models returned similar, but not identical, qualitative results as in Table 9 . In Model 1, the difference between STATE PENSION-FREQUENT ATTORNEY and STATE PENSION-INFREQUENT ATTORNEY is now significant at the 1 percent level. In Model 2, in contrast, the difference between STATE PENSION-FREQUENT ATTORNEY CONTRIBUTION and STATE PENSION-FREQUENT ATTORNEY NO CONTRIBUTION is nOw beyond conventional statistical significance (at the 13.4 percent level).
} 
robust regression to control for the possibility of outliers, ${ }^{39}$ and reestimated the models only for cases that involved at least one institutional investor lead plaintiff. ${ }^{40}$ The results are largely consistent with those reported in Table 9.

\section{Case Selection}

Another question raised by the apparent agency cost problems raised by campaign contributions is whether such contributions might influence case selection. Do campaign contributions induce state pension funds to bring low-value suits?

To assess this possibility, we first estimate a logit regression with the same independent variables as Table 5, Model 1 . Our binary dependent variable equals 1 for cases that produced a dismissal or settlement for a low value, which we define as $\$ 3$ million or less. This is a conservative estimate of defense costs, so we presume that settlements for less than that amount had relatively little merit, although some of these suits may have involved insolvent issuers with significant directors and officers insurance coverage issues.

The results, untabulated, do not support the proposition that plaintiff type correlates with case quality. The coefficients for STATE PENSION, LOCAL PENSION, LABOR UNION, and OTHER INSTITUTION are all insignificant. We find no evidence that institutions are either more or less likely to bring weak claims.

We then attempted to estimate the same logit regression with the independent variables from Table 6, Model 1. The regression would not run. Further investigation revealed that CONTRIBUTION was perfectly correlated with suits that settle for above $\$ 3$ million. We conclude that there is no evidence that campaign contributions induce state pension funds to appear as lead plaintiffs in cases of dubious merit; rather, campaign contributions appear to be a tool that plaintiffs' lawyers use to gain advantage in the competition to be appointed class counsel in cases that attract multiple plaintiffs' firms, which are likely to be the cases with the most obvious evidence of fraud and the greatest potential damages. We speculate that there is no need to pay to gain lead counsel status in weaker cases because there is unlikely to be competition.

\section{Conclusion}

Congress adopted the lead plaintiff provision of the PSLRA because members of Congress believed that individual investors were mere figurehead plaintiffs who did little to monitor

\footnotetext{
${ }^{39} \mathrm{We}$ obtained different qualitative results when we reestimated the models in Table 9 using robust regression with the following difference. In Model 1, the difference between STATE PENSION-FREQUENT ATTORNEY and STATE PENSIONINFREQUENT ATTORNEY is now significant at the 1 percent level. In Model 2, in contrast, the difference between STATE PENSION-FREQUENT ATTORNEY CONTRIBUTION and STATE PENSION-FREQUENT ATTORNEY NO CONTRIBUTION is no longer significant.

${ }^{40}$ Unreported, we obtained similar qualitative results as in Table 9 with one difference. In Model 2, the difference between STATE PENSION-FREQUENT ATTORNEY CONTRIBUTION and STATE PENSION-FREQUENT ATTORNEY NO CONTRIBUTION is now significant at the 5 percent level.
} 
plaintiffs' attorneys. Institutional investors, it was believed, would serve as more active monitors. The evidence to date suggests that institutional investors have made a difference in bargaining for lower fees, which likely translates into greater net recovery for investors. Those findings are confirmed here with respect to state pension funds in general. We also find that local pension funds, although generally having smaller stakes in class action recoveries, appear to negotiate lower fees than individuals.

Congress worried, however, that the benefits of the lead plaintiff provision could potentially be undermined by side payments from counsel to the lead plaintiffs. The PSRLA prohibits lead plaintiffs from obtaining more than their pro-rata share of settlement amounts. Are the political contributions received by the state pension funds that we document a form of selective benefit coming at the expense of the class?

We find that political contributions influence attorney fees. The evidence presented here shows that the hard bargaining by state pension funds largely disappears when decisionmakers for those funds receive political contributions-particularly when those contributions are large. Indeed, when it comes to negotiating for fees, state pension funds that take large contributions are indistinguishable from the figurehead individual investors that Congress targeted with the PSRLA.

Our findings have potentially important policy implications. Courts have generally been skeptical of allegations of pay to play in the selection of class counsel, with some suggesting that the problem is more theoretical than real. We have shown, however, that pay to play imposes a real cost on investors in class actions, who end up paying greater attorney fees out of their recovery. Courts may be justified in taking a closer look when state pension funds that have received political contributions from the firms representing them come forward to seek lead plaintiff status or, at a minimum, when they submit attorney fee requests. The evidence presented here suggests that such institutions should not be presumed to be the vigorous monitors that Congress hoped to attract when it adopted the lead plaintiff provisions of the PSLRA.

\section{REFERENCES}

Choi, Stephen J. (2011) "Motions for Lead Plaintiff in Securities Class Actions," 40 J. Legal Studies 205.

Choi, Stephen J., Jill E. Fisch, and A. C. Pritchard (2005) "Do Institutions Matter? The Impact of the Lead Plaintiff Provision of the Private Securities Litigation Reform Act," 83 Washington Univ. Law Q. 869.

Cox, James D., Randall S. Thomas, \& Lynn Bai (2008) "There Are Plaintiffs and ... There Are Plaintiffs: An Empirical Analysis of Securities Class Action Settlements," 61 Vanderbilt Law Rev. 355 .

Cox, James D., \& Randall S. Thomas with Dana Kiku (2006) "Does the Plaintiff Matter? An Empirical Analysis of Lead Plaintiffs in Securities Class Actions," 106 Columbia Law Rev. 1587.

Dewan, Shaila K. (2002) "Donors to McCall Profit in Cases State Pursues Against Corporate Wrongdoers," August 14 New York Times B4.

Eisenberg, Theodore, \& Geoffrey P. Miller (2004) "Attorney Fees in Class Action Settlements: An Empirical Study,” 1 J. of Empirical Legal Studies 27.

Francis, Jennife, Donna Philbrick \& Katherine, Schipper (1994) "Shareholder Litigation and Corporate Disclosures," 32 J. of Accounting Research 137. 
Perino, Michael A. (2006) Institutional Activism Through Litigation: An Empirical Analysis of Public Pension Fund Participation in Securities Class Actions. St. John's Legal Studies Research Paper Series.

Heckman, James J. (1979) "Sample Selection Bias as a Specification Error," 47 Econometrica 153.

Johnson, M. F., K. K. Nelson, \& A. C. Pritchard (2007) "Do the Merits Matter More? The Impact of the Private Securities Litigation Reform Act," 23 J. of Law, Economics E Organization 627.

Johnson-Skinner, Drew T. (2009) "Paying to Play in Securities Class Actions: A Look at Lawyers' Campaign Contributions," 84 New York Univ. Law Rev. 1725.

Jones, Christopher L. \& Seth E. Weingram (1996) The Determinants of 106-5 Litigation Risk. Working Paper, Stanford Law School.

Perino, Michael A. (2006) Institutional Activism Through Litigation: An Empirical Analysis of Public Pension Fund Participation in Securities Class Actions. St. John's Legal Studies Research Paper Series.

— (2008) The Milberg Weiss Prosecution: No Harm, No Foul? 11 Briefly..., American Enterprise Institute Monograph.

Selvin, Milly (2008) "Plaintiff-for-Hire Sentenced: A Retired Lawyer Gets Home Detention in the Milberg Weiss Case," January 29 Los Angeles Times.

Simmons, Laura E. \& Ellen, M. Ryan (2005) Post-Reform Act Securities Settlements. Cornerstone Research.

Webber, David H. (2010) "Is 'Pay-to-Play' Driving Public Pension Fund Activism in Securities Litigation?" 90 Boston Univ. Law Rev. 2032.

Weinberg, Neil, \& Daniel Fisher (2004) "The Class Action Industrial Complex," September 20 Forbes.

Weiss, Elliott J., \& John S. Beckerman (1995) "Let the Money Do the Monitoring: How Institutional Investors Can Reduce Agency Costs in Securities Class Actions,” 104 Yale Law J. 2053. 


\title{
Appendix: Variable Definitions
}

\author{
Key Independent Variables
}

Variable

Description

Public pension

State pension-contribution

State pension-contribution all state officials

State pension-large contribution

State pension-small contribution

State pension-no contribution

State pension-large losses

State pension-small losses

State pension-frequent attorney

State pension-infrequent attorney

Local pension

Labor union

Other institution
The fraction of lead plaintiffs in a case that consists of a public pension fund.

The fraction of lead plaintiffs in a case that consists of state pension funds with officials, or officials who appointed board members, who received political contributions from the lead attorneys.

The fraction of lead plaintiffs in a case that consists of state pension funds where the lead attorneys have donated to any elected official or party committee in the state.

The fraction of lead plaintiffs in a case that consists of state pensions whose officials received contributions of $\$ 10,000$ or more during the four-year period from two years prior to one year after the suit filing.

The fraction of lead plaintiffs in a case that consists of state public pensions whose officials received contributions of less than $\$ 10,000$ during the four-year period from two years prior to one year after the suit filing.

The fraction of lead plaintiffs in a case that consists of state pension funds with officials who did not receive political contributions from the lead attorneys.

The fraction of lead plaintiffs in a case that consists of state pension funds with a claim over $\$ 1$ million in a given case.

The fraction of lead plaintiffs in a case that consists of state pension funds with a claim of $\$ 1$ million or less in a given case.

The fraction of lead plaintiffs in a case that consists of state pension funds appearing at least twice in our sample that are represented by the same law firm in over $75 \%$ of the cases in our sample where the public pension fund acts as lead plaintiff.

The fraction of lead plaintiffs in a case that consists of state pension funds that appeared only once in our sample or were not represented by the same law firm in over $75 \%$ of the cases in our sample where the public pension fund acts as lead plaintiff.

The fraction of lead plaintiffs in a case that consists of local government pension funds.

The fraction of the lead plaintiffs that consists of a labor union.

The fraction of lead plaintiffs in a case that are institutions but not public pensions or labor unions. 


\section{Appendix Continued}

Other Independent Variables

Case Control Variables Description

Section 11

Section 14

Gov't investigation

Restatement

Officer term.

Auditor term.

Insider trading

Market capitalization

Settlement amount

High tech

FDA

Top attorney firm
Indicator variable equal to 1 if the complaint for a particular class action alleged a Section 11 of the Securities Act of 1933 violation; 0 otherwise.

Indicator variable equal to 1 if the complaint for a particular class action alleged a Section 14 of the Securities Exchange Act of 1934 violation; 0 otherwise.

Indicator variable equal to 1 if the complaint indicated the presence of a SEC or other governmental investigation or enforcement action relating to the fraud at issue; 0 otherwise.

Indicator variable equal to 1 if the complaint indicated that the company announced a restatement covering at least part of the class period; 0 otherwise.

Indicator variable equal to 1 if the complaint indicated that a top officer of the defendant company resigned or was terminated during the class period; 0 otherwise.

Indicator variable equal to 1 if the complaint indicated that the auditor resigned or was terminated during the class period; 0 otherwise.

Indicator variable equal to 1 if the complaint alleged insider trading; 0 otherwise.

Market value of a company's common equity (in \$ millions) at the end of the fiscal year preceding the beginning of the class period.

The settlement amount for the class action (in \$ millions).

Indicator variable equal to 1 if the firm is in SIC codes $3570-3577$ or $7370-7379$; 0 otherwise.

Indicator variable equal to 1 if the last amended complaint for a particular class action is based on U.S. Food and Drug Administration related disclosures; 0 otherwise.

Indicator variable equal to 1 if any of the lead counsel in the specific class action participated 50 or more times as a lead counsel in a class action in the data set; 0 otherwise. The top attorney firms include Milberg Weiss Bershad Hynes \& Lerach LLP, Milberg Weiss Bershad \& Schulman LLP, Lerach Coughlin Stoia Geller Rudman \& Robbins LLP, and Schiffrin \& Barroway LLP. 